\title{
Brief thesis on the meaning of human life
}

\begin{abstract}
This article represents an effort to bring together key ideas about the meaning of life, specifically, human. Understand what life is and what distinguishes him from death, should be one of the first questions to answer, especially when you want to operate on humans. Aiming to answer what means human being, then, firstly, it is concluded as soon as his psyche has developed spirit as supramecanicismo. It also has the will to order its outside for their survival and their offspring, or at least it should be. Finally, the human being, seek material and spiritual satisfaction, always with human dignity, both for himself and for others.
\end{abstract}

Keywords: human dignity, supramecanicismo, human life
Volume 4 Issue 4 - 2019

\section{Arturo Valdivia Loro}

Architect, Department of scientific and technological research, National University of Callao, Peru

Correspondence: Arturo Valdivia Loro,Architect, Department of scientific and technological research, National University of Callao, Peru, Email artuo.valdivia@upn.edu.pe

Received: August 06, 2019 | Published: August 29, 2019

\section{Understanding life}

Conceive what is life, Who are we? is essential to begin reasoning about the humanity of the human being and to understand the existence of others and the interactions between all through the order, disorder, organization and disorganization. ${ }^{1}$ People are biological beings, with biogenetic unit and physically animated, with biochemical unit ${ }^{1}$ they are immersed in a basic and complex discussion: When something comes to life? in order to understand their own existence that goes from what he declared as the cosmic and biological rootedness.

\section{What is life?'}

"We are stardust" is probably the assertion Carl Sagan. ${ }^{2}$ It gives better understand the origin of life, because "we are the legacy of 15 billion years of cosmic evolution." Human beings considered alive, there is a contradiction, as its material, itself is comprised of inert atoms constituting the body and which is then formed with the origin of the universe on a random or intended to develop biochemical. ${ }^{1}$ So the question is, How long nonliving matter acquired this concept? On the other hand, man, using his hand and mind, creates life-or at least simulated bounds near ethics imposed by their culture and society. ${ }^{3}$ Therefore currently it has the capacity to endow inanimate objects, through technology, image and likeness, exactly as symbolically human thought about some creative God, leaving or not your noosfera ${ }^{2}$ another object believed to own, to what has been called artificial life. Life as a concept involves a peculiarity or quality of matter, because all beings are composed of inorganic matter, that is, life as it is known, is actually the best you have found the human being to understand their qualities that differentiate it with other materials that do not have similar qualities, for it separates the human death of his humanity taking the life that gives, through learning, especially the language and mentality. In the human case, if a person loses a leg or an arm, still alive, without assuming if the arm or leg had life in themselves. Making life as beginning, is not present in the field to itself called the human body but in mind be and therefore managed by the processes

$1_{\text {the same question was asked Schrödinger enunciated }}{ }^{4}$ in its publication: what is life? As is seen, as said author, that life can be formulated and understand, although the human is still on the way to achieve a specific response.

2 "Average driver and messenger of the human mind, it communicates with the world while forming a screen between us and the world $[. .$.$] is a transformer$ split and transfiguring of reality that is overprinted on reality, seems confused with it $[\ldots]$ without it could not be done nothing that is human "1 of the brain, or some system similar character ${ }^{3}$ Such as a computer. Just be aware that the idea of life exists as such, without necessarily involving the quality of it.

Life as mechanistic, is linked to an action-reaction through the operability and human activity ${ }^{6}$ while for organicists it is related to a value added when the product is more than the sum of its parts. ${ }^{7}$ Likewise it is possible to stumble upon tautological definitions, literary, physiological, psychological, energy, biological and philosophical. ${ }^{8}$ However, it is animism, through Gaia theory ${ }^{9}$ which proposes a different way of understanding life as it states that the planet itself has vitality. However, life is exposed to death, forged by the arrow of time ${ }^{10}$ the universe and determines three fundamental questions:

1. The concept of death is irreversible, ie it is not possible to return to the quality of life after the expiry. ${ }^{4}$

2. Life consists in the effort of being to avoid the continuity of time $^{5} \mathrm{Ie}$, avoids his own death.

3. Every object has DNA alive ${ }^{6}$ as genes inherited memory and experience possessed ancestors and they trasmitieron. ${ }^{7}$

While defining life is soporific and unintelligible ${ }^{8}$ their understanding is contingent on the dialectic with that which is not, so it is important to achieve the characteristics that define them as it will delve into other concepts such as quality of life and human dignity and therefore also in human rights, topics that are not developed in this article, however, many authors confuse, in the case of very different definitions

${ }^{3}$ Human beings, aware that it is not the only species alive, gives this quality to every being that has similar characteristics. ${ }^{5}$

4 "Death is not only the decomposition of a body, it is both the annihilation of a subject"1

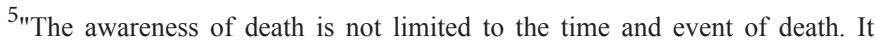
presents to death in life"1

${ }^{6}$ This concept also discussed and accepted Capra, ${ }^{14}$ Schrödinger, ${ }^{4}$ who understands as gen-, Romecín Maturana \& Varela, Francisc ${ }^{15}$

7 "Gene means [...] biological and cultural heritage, freight and gift, determination and autonomy, limitation and possibility, necessity and freedom"1

${ }^{8}$ Horacio Bernardo. ${ }^{7}$ For example, it states that semantically define life is impossible. 


\section{What characteristic has something alive?}

Jakob $^{11}$ Life has seven characteristics:

1. Causal closure of nature which it consists of a covered claim in the evolution of matter ${ }^{9}$ as soon as the matter has created matter at a given time. ${ }^{12}$ Therefore, the mind and all that implies, is a quality of life, at least in terms of production.

2. Energetics, deals with the sustenance that all physical action is generated by energy and, therefore, as life is quality of matter that has been created by events of matter, then, it is also possible to explain its physical aspects with energy formulas.

3. Supramecanicismo term related to the animal mechanical automatism, which although in its theistic definition denies the soul within the animal kingdom shall be considered due to the entelequia ${ }^{10}$ Aristotle says that ${ }^{13}$ and the bore of Morin. ${ }^{1,11}$ It can be understood as the will of the soul it emerges and projects into the spirit.

4. Self-regulation, anti-entropic power and organizational continuity, from the foregoing, it combines self-regulation, perhaps principle of evolution, in terms of natural experimentation whose principle is that the subject matter survive. From this perspective, one can say that there is a possibility that life really is the intent of the material to prevent its destruction, so even human intelligence, is an effect to prolong the state or quality of life. For this purpose, inert matter, or energy, is organized into amino acids, cells, organs, animals, societies, planets, among others, to survive, or rather, to keep as much as possible their condition.

5. Psychism, based mental aspect of all matter with quality of life, which gives existentialism, generating what is defined as mind giving sensitivity, imagination, creativity and intelligence to life. Morín ${ }^{1}$ notes the psychic from an anthropological perspective from the psycho-emotional, in relation to otherness and from homo hystericus, consumans and ludens.

6. Aristotelian soul (form) indiscerniente of existentiality, it will be understood as having the particularity the body due to gene or DNA having and determines their existence as alive.

7. Reduction psyche your mind; or spirit as a set of mental contents, at this point he questions what is located where the spirit? And it concludes that social projection of the mind, therefore a human embryo has soul but not spirit, whereas when born then has both.

Therefore, life is the accumulation of matter organized to ensure the survival of their subject and self-organized and constantly improving, through genes, in order to overcome the arrow of time, ${ }^{10}$ That trend destroy it seeks expansión. ${ }^{16}$ The matter then was formed to selfregulate the matter of the environment it inhabits, developing psychic in the animal kingdom. To this end, it has evolved to emerge mentality

${ }^{9}$ It can function generally and that, however, differs from the human condition, as it requires the mindset to the genesis of human affective unity before death, as well as cultural and sociological. ${ }^{1}$

${ }^{10}$ Or the act of living being. In human life, it is a philosophical difference between the lower and upper soul as a system that roams between generative, nutritional and sensory foundations importance.

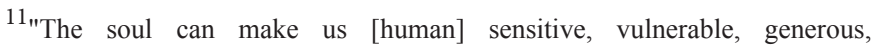
compassionate, open to the world and other subjects". ${ }^{1}$ to endure his soul using its power through its supramecanicismo. Matter desires endure as measured gene to prevent death involving chaos, disorder and disorganization of the automaton matter: the body, so that the DNA determined as a basic tool to resist death. Because of these conditions is that it is impossible to reverse this state, then chaos is found throughout the body: the way he acquired the matter.

\section{Human life}

If life is a quality of matter, the human condition is a quality of this quality. That is, life involves everything possessing the above characteristics, so they have created different kingdoms involving animals, insects, plants, bacteria, fungi and so on. Human, is part of one of these kingdoms as the top animal, but still be one more species. However, it is characterized and unlike other species as developed consciousness beyond instinct, that is, through reason and language and developing these characteristics a form of organization that is distinguished from other species: philosophy and art. Human life, then, involves creativity, not only for your social life, individual or secret. ${ }^{17}$ But also it produces for the acquiescence of others. The human being, then look not only their own welfare but that of others perhaps through the material and spiritual, using Immaculately human inventions. Music, theater, sculpture, dance, literature, cinema, architecture and knowledge.

\section{What is the human being?}

Being implies the existence of something, whether or not a physical object, because in reality, is just a rational being, as man, he is able to recognize the being of something ${ }^{18}$ Providing existence. Being there, with no rational matter that understand and define, however, is only the matter who studies and analyzes, perceiving himself and proving their existence in relation to others. That is, there is someone without first think, but when you think about it comes into existence for the rational being who studies it. As gives it life, then it gives you a definition, assigning each name to be using their rationality and linguistics.

Being is everything that man perceives or feels in considering Schopenhauer. ${ }^{19}$ Therefore, being the product of reality and mind of matter that study. However, all that product of the mind, will end with the destruction of matter that has thought, that is, in his death. Consequently, it is possible to distinguish:

1. What it exists and is thought

2. What is thought and there

3. What does not exist and is thought

4. And what it is not thought out and there

As for the human it is framed as defined above as human life, but not necessarily imply that humanity possesses that matter, so two features distinguish: as rational animal species, in analogy to what mentioned by Arend $\mathrm{t}^{20}$ nature and condition is possessed respectively and hastening the possibility of scales, because "the human person becomes more human". ${ }^{17}$ While human nature is related to the material aspect, the human condition is associated with the product mentality culture society ${ }^{20}$ what emerges Jakob ${ }^{11}$ he understood as the spirit. Therefore, the human being lives between two aspects:

1. Materially

2. Spiritually 
These two aspects, also mentioned by Torres Bardales, ${ }^{17}$ Coupled by the conditions of being they have raised several discussions and currents of thought to try to understand what it means and human existence itself has not caused should agree on what it means humanity. ${ }^{21}$

\section{Final elevation: What does it mean to be human?}

In principle the human being is a material entity, which is registered in the animal kingdom ${ }^{12}$ According to the same definitions of human being who, because of their instinct for survival, has also developed a social life, separating his personal life with the public and reserving one for himself for the benefit of oneself and others. It differs from other species, as his psyche has developed spirit as supramecanicismo that is driven by desire both material and spiritual emerges not biological evolution but cultural and social, creating philosophy and art using and developing their language and reason, fully aware of their relationship with other entities through symbolism that has generated the same humanity: the values so that through it, generate dignity in himself and in others. People, then it means, having empathy for other beings are material or not. It also means having the living conditions and human life, ie, a human being, must order its outside for their survival and that of their offspring, or at least it should be., Since the objective is to transmit and ensure persistence of its gene or DNA, in full material and spiritual satisfaction using philosophy and art. However, they are also human beings who do not reach consciousness of humanity will be treated minors who are with tutor.

In addition, human being, involves providing value their existence: life+justice + Freedom + Peace + honor ${ }^{17}$ in order to achieve dignity and not necessarily for himself, but to dignify the existence of other beings through respect and finally, society emerges as a resistance force that adds several individuals. Every human being will have its own mentality, it is to be built by each company, reflecting its cultura ${ }^{22}$ individual and collective way. Possessing humanity's own culture, urbanity, individuality and autonomy, belonging to the species of a kingdom of life, struggling with the arrow of time, own DNA and finally be alive. ${ }^{23}$

\section{Acknowledgments}

None.

\section{Conflicts of interest}

Author declares that there is no conflicto of interest.

\section{References}

1. Morin E. The method. E. Morin, humanity of mankind. Human identity. Madrid. Spain: Chair; 2003.

\footnotetext{
${ }^{12}$ Therefore it is an organism. ${ }^{23}$
}

2. Haines-Stiles G, Kennard D. Sagan C, et al. Cosmos [Film]. 1980.

3. Bolivarian government of Venezuela. Code of Ethics for life. Caracas, Venezuela: Ministry of Popular Power for Science, Technology and Intermediate Insdustrias; 2011.

4. Schrödinger E. What is life? Barcelona, Spain: Tusquets; 1983.

5. Sierra Mendoza LA, Mendoza Sierra E. Biology I. Mexico DF, Mexico: Trillas; 2009.

6. Lopez Alvarez P. Materialism. In: J Munoz, editor. Espasa Dictionary filosofi, Madrid, Spain: Espasa-Calpe; 2003. p. 568-576.

7. Bernardo H. What is life? An epistemological problem. Rei Part A. 2004;33:11.

8. Carrillo R. What is life? Electroneurobiology. 2000;7(1):1-43.

9. Lovelock J. Gaia, a new vision of life on earth. Barcelona, Spain: Orbis; 1985.

10. Eddington A. The nature of the physical world. Cambridge, England: The University Press; 1948.

11. Jakob C. The scientific definition of life. Revista del Museo Social Argentino. 1948;313-314,193-203.

12. Strand A. The Metaphysics of Mental Causation. Ph.D. Thesis in Philosophy, University of Oslo, Department of Philosophy, Classics, History of Art and Ideas, Oslo; 2007.

13. Aristotle. About the soul. (T. Calvo Martínez, Trad.). Basic Library Gredos; 2011.

14. Capra F. Hidden connections. Barcelona, Spain: Ediciones Anagram; 2003.

15. Romecín Maturana H, Varela Francisco. Knowledge tree: the biological basis of human understanding. Santiago de Chile, Chile: Universidad de Chile; 2009.

16. Hawking S. History of Time. Bing bangs to black holes. Barcelona, Spain: Criticism; 2008.

17. Bardales Torres C. Philosophical foundations of human dignity and their impact on human rights. PhD, Mayor de San Marcos National University, Faculty of Arts and Humanities, Lima; 2015.

18. Robles Sotomayor E. Being and essence. Mexico City, Mexico: Faculty of Law of the UNAM; 1991.

19. Schopenhauer A. The quadruple root of the principle of sufficient reason. Buenos Aires, Argentina: El Ateneo; 1950.

20. Arendt H. The human condition. Buenos Aires, Argentina: Paidos; 2009.

21. Barbosa de Magalhães V. The concept of humanity in the social sciences. Magazine Society and Economy. 2009;17:215-228.

22. Durkheim É. Dualism of human nature and social conditions (1914). Lattices and perspectives. 2011;1(1):189-200.

23. Hegel GW. Phenomenology of Spirit. Mexico City, Mexico: FCE; 1993. 